\title{
Coefficients of relationship and inbreeding among Finnish Ayrshire and Holstein-Friesian
}

\author{
Terhi Vahlsten \\ MTT Agrifood Research Finland, Animal Production Research, Animal Breeding, FI-31600 Jokioinen, Finland. \\ Present address: Sepontie 3 H 46, FI-02130 Espoo, Finland, \\ e-mail:terhi.vahlsten@welho.com \\ Esa A. Mäntysaari and Ismo Strandén \\ MTT Agrifood Research Finland, Animal Production Research, Animal Breeding, FI-31600 Jokioinen, Finland
}

\begin{abstract}
Pedigree data from national breeding value evaluations were used in calculation of the coefficient and rate of inbreeding, average coefficient and rate of relationship and generation intervals for the Finnish Ayrshire and Holstein-Friesian dairy cattle populations. The data had 1,366,555 Ayrshire and 377,869 Holstein-Friesian animals. The mean coefficient of inbreeding for Ayrshire and Holstein-Friesian animals born in the 1990 s was $2.29 \%$ and $0.90 \%$, respectively, and the trend was towards higher inbreeding values. The average coefficient of relationship, mean increase in inbreeding and generation interval was calculated for bulls born between 1976 and 1999, and for cows born between 1986 and 1999. The mean coefficient of relationship of Ayrshire bulls increased $2.22 \%$-units per generation and inbreeding increased $0.20 \%$-units per generation during the years studied. The mean coefficient of relationship of Finnish Holstein-Friesian bulls increased $0.96 \%$-units per generation and inbreeding $0.17 \%$-units per generation. The mean coefficient of relationship and inbreeding of Ayrshire cows increased $0.38 \%$-units and $0.31 \%$-units per generation, respectively. For Holstein-Friesian cows the mean coefficient of relationship and inbreeding increased 0.25 $\%$-units and $0.11 \%$-units per generation, respectively. Results show that inbreeding is low and it is increasing slowly in both breeds. However, especially the coefficients of relationship of Ayrshire bulls are high in some age classes and this may lead into faster increase in coefficients of inbreeding.
\end{abstract}

Key words: Ayrshire, Holstein-Friesian, inbreeding, relationship, generation interval

\section{Introduction}

Dairy cattle breeding uses resources globally. The best bulls are used and embryos can be bought all over the world. Breeds are not limited to one or a few countries', but they are world wide big families. This is no doubt advantageous for genetic and economic improvement, but it can also have negative side effects. Impact of top bulls has become enormous and hence animals are becoming ever more closely related. Development is also acceler- 
Vol. 13 (2004): 338-347.

ated by common selection based on the best linear unbiased prediction (BLUP) method which favours use of relatives. Thus inbreeding inevitably increases and effective population sizes decreases'. It is estimated that the effective population sizes $\left(\mathrm{N}_{\mathrm{e}}\right)$ of US Holstein and Ayrshire populations are 39 and 161 animals, respectively (Weigel 2000). Estimates of inbreeding in European and NorthAmerican dairy cattle populations indicate that the rate of inbreeding is indeed increasing (Casanova et al. 1992, Wiggans et al. 1995, Woolliams and Mäntysaari 1995, Thompson et al. 2000a, b).

Small effective population size means that only few animals will genetically contribute to future generations. Eventually this leads into loss of genetic variation and biodiversity. On the other hand, inbreeding has economic value because it leads into inbreeding depression, which is usually observed in reproductive (Hermas et al. 1987) and survival traits (Thompson et al. 2000a, b) but also in milk production traits (Smith et al. 1998).

The Finnish Ayrshire population was originally developed from 1562 Ayrshire animals from Scotland and 303 from Sweden (Simonen 1950). Since then, first bulls and later semen has been imported from Norway, Canada and the USA. The co-operation with other Nordic countries, especially with Sweden and Norway, has traditionally been very close in Ayrshire breeding. During the last few years the breeding organisations have intensified their co-operation even more. Nowadays AI bulls in Finland, Sweden and Denmark get their first breeding values while still alive which enables the Nordic countries to use the best AI bulls more efficiently. Thus in the future, there will be single combined Ayrshire population in the Nordic countries.

The first Finnish Black and White animals were Friesians imported from Sweden and Denmark in the 1960s (Lonka and Myllylä 1988). At the same time semen from Swedish Friesian bulls was used to introduce Friesian blood into Finncattle and into some Ayrshire herds by continuous crossbreeding. The Finnish Black and White cattle are nowadays called Finnish Holstein-Friesian cattle because most of the imported semen after the late 1970s has been Holstein from North American origin. In the last few years Finland has imported Holstein semen from France and the Netherlands as well. Thus the Finnish Black and White cattle are nowadays more and more part of the international Holstein breed.

Finland tests about 130 Ayrshire and 55 Holstein-Friesian bulls annually (FABA 2004). The number of test bull doses is about 1400 which are used in milk recorded herds. About $40 \%$ of inseminations in Ayrshire and Holstein-Friesian cattle populations are performed with young sire semen to guarantee progeny testing of large number of dairy bulls with sufficient accuracy. Some $50 \%$ of cows are inseminated with best proven bulls. About $75 \%$ of Ayrshire and Holstein-Friesian cows are included in milk recording system (FABA 2004).

The level and rate of inbreeding in the population have to be monitored at times. In Finland this has been done for the sixties by Lindström and Maijala (1971) and for the eighties by Woolliams and Mäntysaari (1995). In the 1990s the breeding program and breeding objectives slightly changed, the Ayrshire nucleus herd started and international trade increased. Thus it is time to update the coefficients of inbreeding and relationships in order to know their current level after these changes.

Purpose of this study was to calculate the current coefficient and rate of inbreeding, the coefficient of relationship and generation interval in the Finnish Ayrshire and Holstein-Friesian populations.

\section{Material and methods}

The data were all the available pedigree information of the animals that are included in the breeding value evaluation in Finland. These include all milk recorded cows that have calved since 1988 and their sires and dams when known. In evaluation data the dams of the cows in production are used (Table 1), but after first parental generation only pedigrees of the sires are traced. For this study the sire pedigrees were traced as far back as possible. 
Vahlsten, T. et al. Coefficients of relationship among Finnish dairy cattle populations

Table 1. Number of bulls and cows according to the year of birth and the number of their unknown sires and dams.

\begin{tabular}{|c|c|c|c|c|c|c|c|}
\hline & \multicolumn{7}{|c|}{ Year of birth } \\
\hline & Unknown & $1950 \mathrm{~s}$ & $1960 \mathrm{~s}$ & $1970 \mathrm{~s}$ & 1980-1985 & 1986-1989 & $1990 \mathrm{~s}$ \\
\hline \multicolumn{8}{|l|}{ Ayrshire } \\
\hline Bulls & 3 & 292 & 1,391 & 2,577 & 1,637 & 978 & 2,302 \\
\hline Sire unknown & & 193 & 96 & 9 & 6 & 3 & 7 \\
\hline Dam unknown & & 159 & 624 & 156 & 22 & 15 & 24 \\
\hline Cows & 2,833 & 298 & 11,140 & 136,051 & 192,174 & 277,178 & 705,640 \\
\hline Sire unknown & 2,563 & 227 & 3,889 & 9,868 & 2,333 & 3,048 & 2,267 \\
\hline Dam unknown & 1,413 & 281 & 10,525 & 52,333 & 17,585 & 17,115 & 29,439 \\
\hline \multicolumn{8}{|l|}{ Holstein-Friesian } \\
\hline Bulls & 7 & 23 & 139 & 522 & 394 & 288 & 947 \\
\hline Sire unknown & & 19 & 33 & 16 & 2 & 2 & 2 \\
\hline Dam unknown & 6 & 21 & 102 & 96 & 31 & 13 & 34 \\
\hline Cows & 534 & 3 & 545 & 22,710 & 43,944 & 68,301 & 219,282 \\
\hline Sire unknown & 432 & 2 & 109 & 1,457 & 1,309 & 1,878 & 2,531 \\
\hline Dam unknown & 412 & 3 & 521 & 9,813 & 7,127 & 6,928 & 14,490 \\
\hline
\end{tabular}

The oldest bulls were recorded to be born in 1930s. However, birth year of most of the early animals was unknown. For the 705,640 Ayrshire cows born in 1990s only 29,439 had unknown dam and 2,267 had unknown sire. The cows with missing dam information were from herds joining the milk recording during 1990s. The data had 1,366,555 Ayrshire bulls and cows and 377,869 HolsteinFriesian bulls and cows.

The pedigree was checked for errors before the coefficients of inbreeding were calculated. There were few animals whose parent information was incorrect e.g. same animal was both sire and dam, and in these cases other parent was set to unknown. There were also few cycles in the pedigree. Cycles were opened by setting one animal's other parent unknown at the end of the cycle. Thus the animal which caused the cycle is no longer ancestor to itself.

The generation interval was calculated for four different pathways: bulls to breed bulls, bulls to breed cows, cows to breed bulls, and cows to breed cows. The generation intervals were averaged over different years and pathways. The year was the year of birth of the offspring, i.e. the average age of parents when their progeny was born.

The coefficient of inbreeding was calculated with the algorithm presented by Meuwissen and Luo (1992). In order to calculate the relationship between two animals, an imaginary offspring was created for them and the relationship between parents was calculated as twice the coefficient of inbreeding of this offspring. Average relationship was calculated within age classes of bulls and cows. For Ayrshire cows the calculation of average coefficient of relationship used a random sample of 24,000 cows each year due to computational reasons. Rate of inbreeding $(\Delta \mathrm{F})$ was calculated by $\Delta \mathrm{F}=\left(\mathrm{F}_{\text {year }}-\mathrm{F}_{\text {year- } 1}\right) /\left(1-\mathrm{F}_{\text {year }-1}\right)$ (Falconer and Mackay 1996) and averaged by year periods. Corresponded formula was used for rate of relationship $(\Delta \mathrm{R})$. The coefficient of inbreeding was calculated for every animal in the pedigree but only animals with known year of birth were included for the calculation of rates and averages of inbreeding and relationship.

\section{Results}

\section{Generation interval}

The generation intervals for four different pathways are presented in Figure 1. In the 1990s the mean L of pathway bulls to breed bulls was 7.9 years for Ayrshire and 8.1 years for Holstein-Frie- 
Vol. 13 (2004): 338-347.

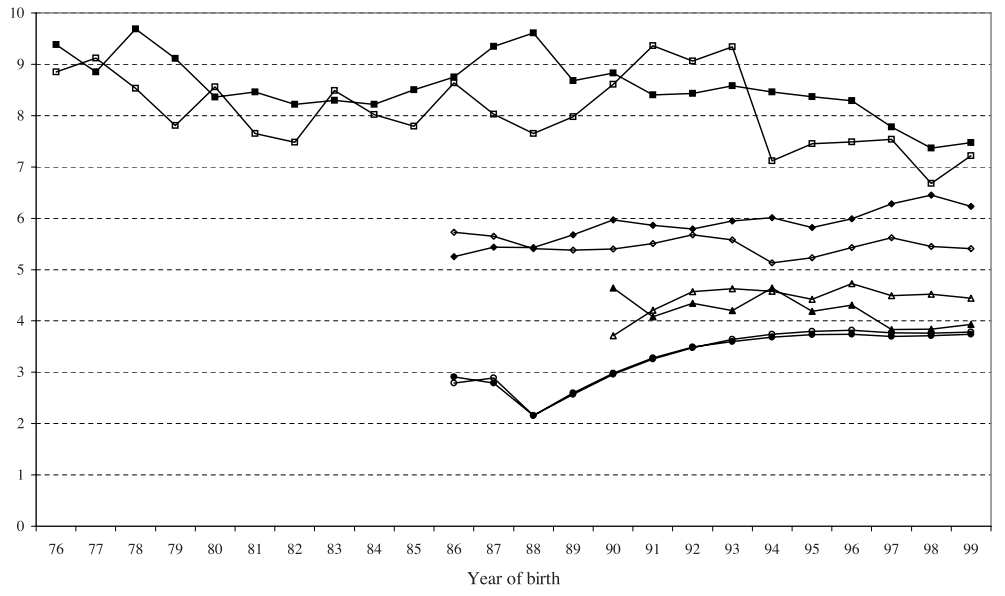

Fig. 1. Average generation intervals (L) of Ayrshire (open marks) and Holstein-Friesian (black marks) for four different pathways: bulls to breed bulls ( $\square$ ), bulls to breed cows $(\bullet)$, cows to breed bulls $(\mathbf{\Lambda})$ and cows to breed cows $(\mathbf{O})$. sian. It took on average 5.5 years for Ayrshire bulls and 6.1 years for Holstein-Friesian bulls to breed cows. For cows to breed bulls- pathway L was 4.5 years for Ayrshire and 4.1 years for Holstein-Friesian and for cows to breed cows- pathway L was 3.6 years for Ayrshire and 3.6 years for HolsteinFriesian. The trend in 1990s has been towards younger bull sires, whilst the age of dams of either bulls or cows has not changed notably (Fig. 1).

\section{Average coefficient and rate of relationship}

The average coefficient of relationship of Ayrshire bulls increased quite rapidly until 1985, after which there was considerable year to year variation, especially at the end of the 1990s (Fig. 2). Increase in rate of coefficient of relationship $(\Delta \mathrm{R})$ per year

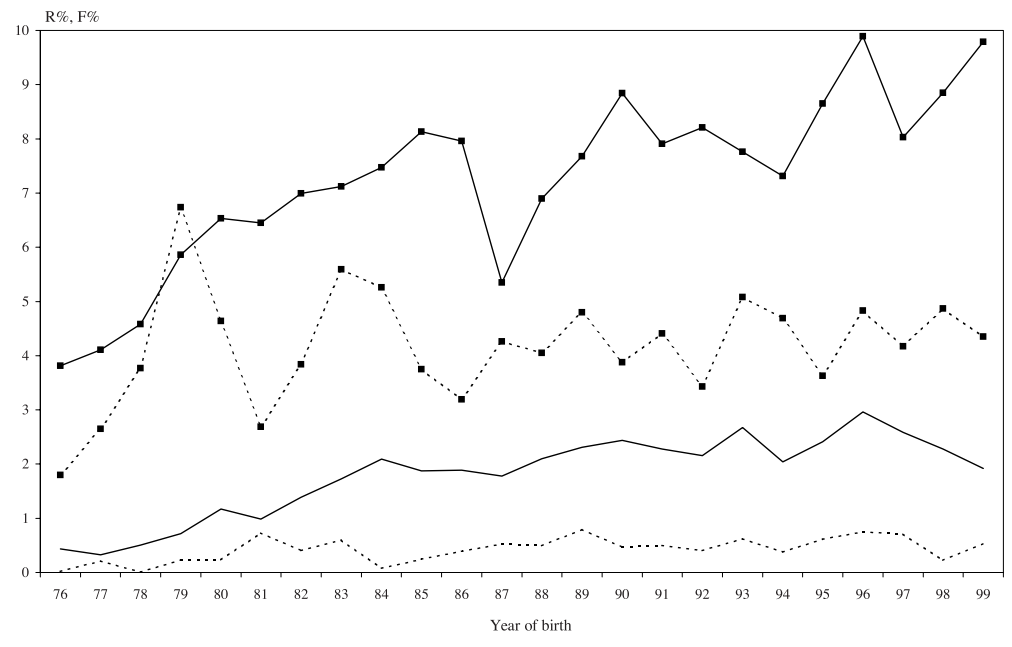

Fig. 2. Average coefficient of relationship (R\%) (ם) and inbreeding $(\mathrm{F} \%)$ of Ayrshire (solid line) and Holstein-Friesian (broken line) bulls born 1976-1999. 
Vahlsten, T. et al. Coefficients of relationship among Finnish dairy cattle populations

Table 2. Rate of increase (\%-units) in relationship $(\Delta \mathrm{R})$ and inbreeding $(\Delta \mathrm{F})$ per year and per generation of Ayrshire (Ay) and Holstein-Friesian (Ho-Fr) bulls in different years.

\begin{tabular}{|c|c|c|c|c|}
\hline \multirow[t]{2}{*}{ Period } & \multicolumn{2}{|c|}{$\Delta R /$ year } & \multicolumn{2}{|c|}{$\Delta \mathrm{F} /$ year } \\
\hline & Ay & Ho-Fr & Ay & Ho-Fr \\
\hline 1976-1979 & 0.71 & 0.71 & 0.10 & 0.05 \\
\hline 1980-1984 & 0.34 & 0.20 & 0.14 & 0.00 \\
\hline 1985-1989 & 0.14 & 0.02 & 0.11 & 0.04 \\
\hline 1990-1994 & 0.04 & 0.06 & -0.01 & 0.00 \\
\hline 1995-1999 & 0.49 & 0.32 & -0.19 & 0.00 \\
\hline 1976-1999 & 0.31 & 0.14 & 0.03 & 0.02 \\
\hline$\Delta \mathrm{R} /$ generation & & & $\Delta \mathrm{F} /$ generation & \\
\hline 1976-1999 & 2.22 & 0.96 & 0.20 & 0.17 \\
\hline
\end{tabular}

was not very fast in the five year periods during the years studied (Table 2). However, the increase per generation between the years 1976 and 1999 was over $2 \%$-units (Table 2). For Holstein-Friesian bulls average coefficient of relationship varied considerably between age classes, but the increase was very slow especially in the 1980 s and beginning of the 1990s (Fig. 2, Table 2). Rate of increase in relationship per generation was almost $1 \%$-units between years 1976 and 1999 (Table 2).

For cows the increase in relationship was very slow during the years studied and it was apparently ceasing at the end of the 1990s (Fig. 3). For Holstein-Friesian cows average coefficient of relationship actually slightly decreased in the end of the 1990s (Table 3). For cows in both breeds the increase in relationship per year and per generation was very slow from year 1986 to 1999 (Table 3).

\section{Inbreeding}

The estimated average inbreeding for the Ayrshire animals born in the 1990 s was $2.29 \%$. The trend in the 1990s has been towards higher inbreeding values (Fig. 4). In 1990 over 40\% of Ayrshire animals had inbreeding values higher than $2 \%$ and in 1999 almost $60 \%$ of Ayrshire's had inbreeding values higher than $2 \%$. The share of non-inbred animals, i.e., animals that have inbreeding value
Fig. 3. Average coefficient of relationship (R\%) (ם) and mean inbreeding (F\%) of Ayrshire (solid line) and Holstein-Friesian (broken line) cows born 1986-1999.

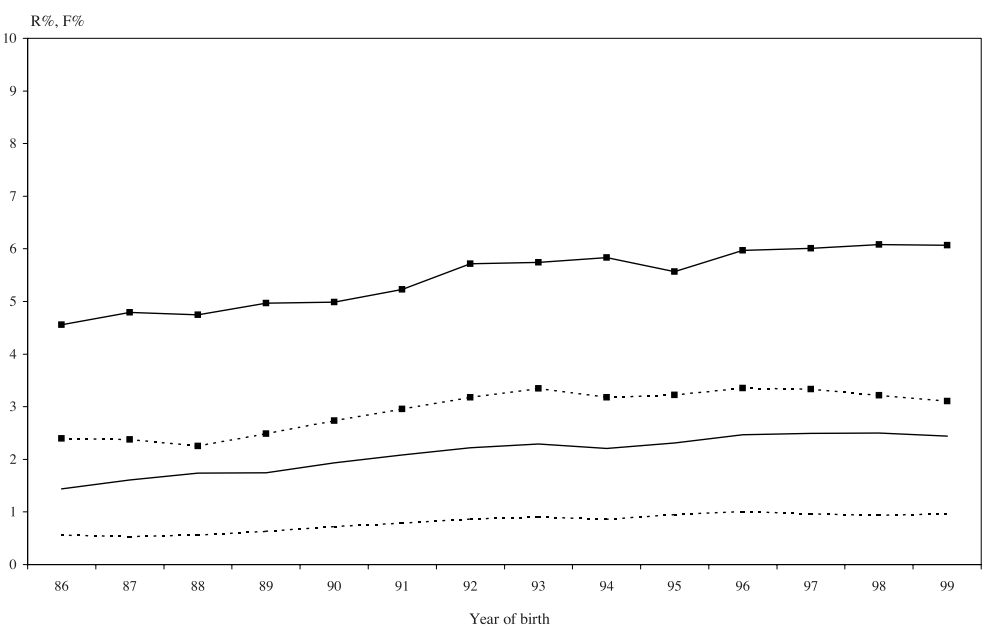


Vol. 13 (2004): 338-347.

Table 3. Rate of increase (\%-units) in relationship $(\Delta \mathrm{R})$ and inbreeding $(\Delta \mathrm{F})$ per year and per generation of Ayrshire (Ay) and Holstein-Friesian (Ho-Fr) cows in different years.

\begin{tabular}{lccccc}
\hline Period & \multicolumn{3}{c}{$\Delta \mathrm{R} /$ year } & & \multicolumn{2}{c}{$\Delta \mathrm{F} /$ year } \\
\cline { 2 - 3 } \cline { 5 - 6 } & Ay & Ho-Fr & & Ay & Ho-Fr \\
\hline $1986-1989$ & 0.11 & 0.09 & & 0.13 & 0.04 \\
$1990-1994$ & 0.12 & 0.10 & & 0.07 & 0.05 \\
$1995-1999$ & 0.01 & -0.03 & & 0.01 & 0.02 \\
$1986-1999$ & 0.08 & 0.05 & & 0.07 & 0.02 \\
SR/generation & & & & $\Delta$ F/generation & \\
1986-1999 & 0.38 & 0.25 & & 0.31 & 0.11 \\
\hline
\end{tabular}

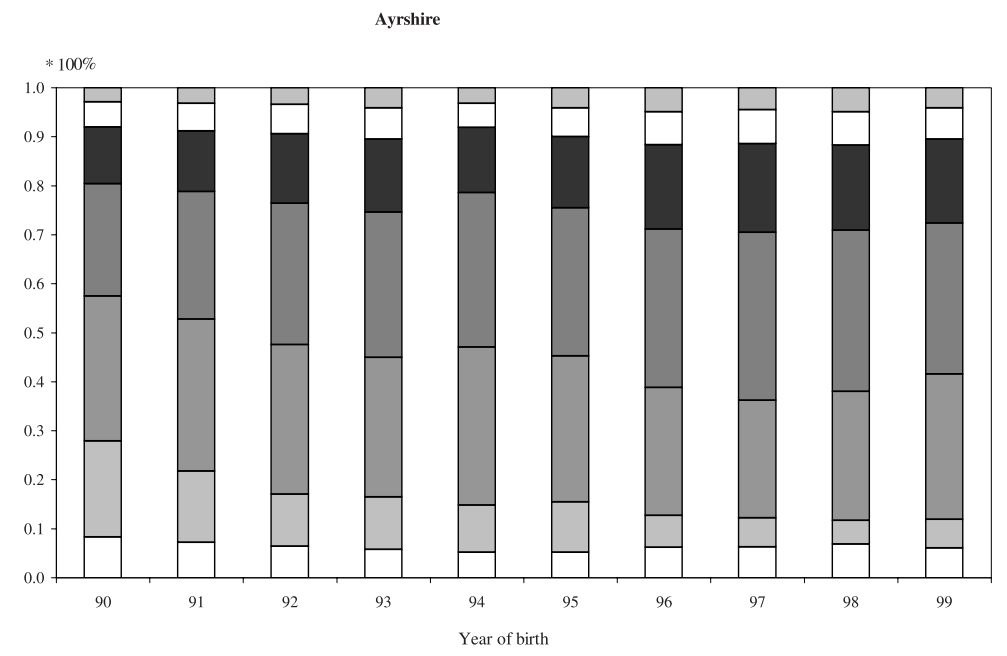

Fig. 4. Distribution of inbreeding values in the 1990s for Ayrshire and Holstein-Friesian. The colours from down to top: first: $\mathrm{F}=$ $0 \%$, second: $0 \%<\mathrm{F} \leq 1 \%$, third: $1 \%<\mathrm{F} \leq 2 \%$, fourth: $2 \%<\mathrm{F} \leq$ $3 \%$, fifth: $3 \%<\mathrm{F} \leq 4 \%$, sixth: $4 \%$ $<\mathrm{F} \leq 5 \%$, seventh: $\mathrm{F}>5 \%$.

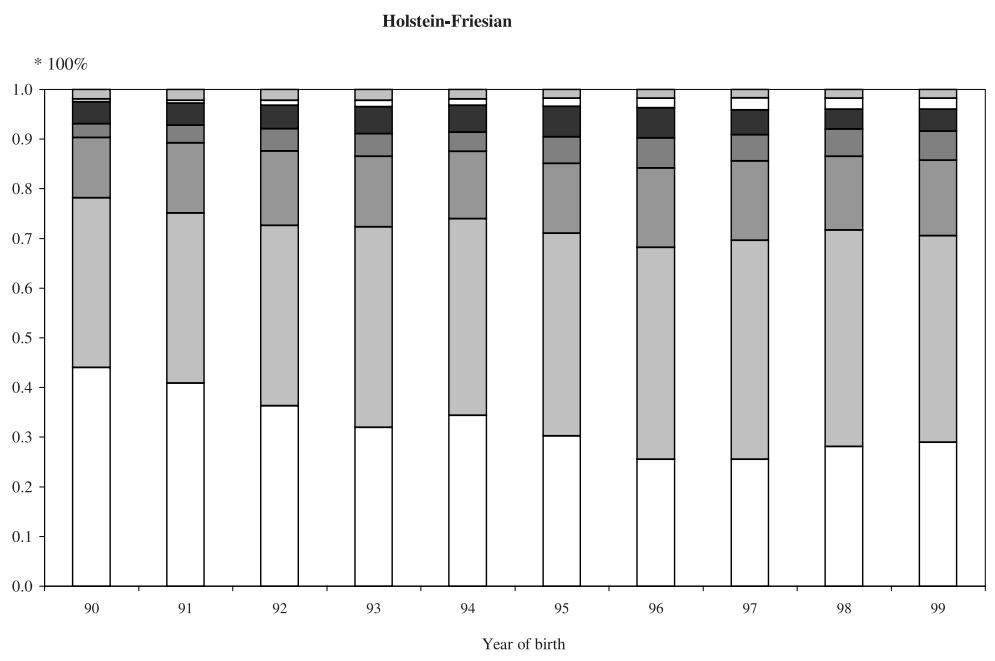


zero, stayed almost the same through the 1990s. Likewise the share of inbreeding values higher than $5 \%$ stayed the same. The share of inbreeding values from $2 \%$ to $4 \%$ has increased most notably during the 1990s (Fig. 4).

The estimated average inbreeding for the Holstein-Friesian animals born in the 1990s was $0.90 \%$. For Holstein-Friesian the trend in 1990s has been towards inbred animals whilst the share of higher inbreeding values has stayed nearly the same (Fig. 4). The share of non-inbred animals has decreased from over $40 \%$ in 1990 to less than $30 \%$ in 1999 (Fig. 4).

\section{Rate of inbreeding}

Mean coefficient of inbreeding of Ayrshire bulls increased quite slowly until the beginning of the 1990s and during the last decade was slightly decreasing (Fig. 2). Mean inbreeding of Ayrshire bulls increased $0.20 \%$-units per generation and for Holstein-Friesian bulls the increase was $0.17 \%$-units per generation (Table 2). For Holstein-Friesian bulls mean inbreeding coefficient increased very slowly during the years studied and in the 1990s it remained at the same level (Fig. 2, Table 2).

For Ayrshire and Holstein-Friesian cows the increase in mean coefficient of inbreeding has been slow and steady (Fig. 3, Table 3). The increase ceased at the end of 1990s and inbreeding stayed at the same level for both breeds (Fig. 3). For Ayrshire cows mean coefficient of inbreeding by year and by generation was greater than for the Ayrshire bulls.

\section{Discussion}

Generation intervals for Ayrshire were shorter than the previous estimates (Lindström 1969, 1978, Woolliams and Mäntysaari 1995). In 1989 bull dams were on average 6.30 years old (Woolliams and Mäntysaari 1995) but in 1999 bull dams were nearly two years younger. Differences in generation interval between breeds were small. Genera- tion intervals stayed at the same level during the 1990s in all pathways except for the pathway of bulls to breed bulls. It seems that nowadays bull is considered as a candidate for bull sire as soon as accuracy of its breeding value is high enough for all traits. Especially Ayrshire bulls are relatively young when their female progeny are born, but it has to be kept in mind that one fourth of all replacement heifers are daughters of test sires. It is possible, however, that in the future the generation interval becomes longer in bulls to breed cows pathway for Ayrshire because AI bulls are kept alive and they can produce semen for many years. Holstein-Friesian bulls used in breeding are somewhat older than Ayrshire bulls. This may be due to the continuous importation of Holstein breed that has lead to slightly higher proportion of use at proven sires.

There have been few previous studies on inbreeding and relationship coefficients in Finnish Ayrshire but none in Finnish Holstein-Friesian. Lindström and Maijala (1971) estimated that the additive genetic relationship increased from 1915 to 1965 at a rate of $0.11 \%$-units per year and inbreeding at a rate of $0.05 \%$-units per year. Mean inbreeding coefficient of AI sires born in 1981 was 0.79\% (Mäntysaari and Strandén 1991) and in this study it was approximately same in 1981 and the coefficients of inbreeding have stayed low during the years studied. Woolliams and Mäntysaari (1995) estimated the increase in inbreeding of bulls by regression from 1974 to 1988, showing a trend of $0.18 \%$-units annually and an increase in the average coefficient of additive genetic relationship of bulls $0.30 \%$ annually. In this study the increase of average coefficient of relationship per year of Ayrshire bulls born during 1995 to 1999 was $0.49 \%$-units per year. There may be several reasons for the increase of coefficient of relationship. One reason for the higher coefficients of relationships is that the pedigree used in this study was more complete and all the available pedigree information was used when the coefficients were calculated. However, the changes in breeding program and objective haven't considerably affected the coefficient of relationship which has increased during the years studied. 
Vol. 13 (2004): 338-347.

Although increase in mean coefficient of relationship per year was relatively slow in our study, average coefficient of relationship between age classes varied a lot and in a few age classes it was very high. Finland has imported semen of Ayrshire AI bulls mainly from Sweden but also from Norway, USA and Canada, and most of these imported bulls have been used as bull sires. Importation of bulls clearly decreased average coefficient of relationship in 1987 and 1988 when almost $30 \%$ of AI bulls were progeny of imported bulls and the steady increase of average coefficient of relationship stopped. The share of imported bulls' progeny has been smaller after this during the 1990s and their effect on average coefficient of relationship has diminished especially in the end of 1990s. During 1990s most of the imported bulls have been from Sweden and many have ancestors in the Finnish Ayrshire population. Thus, importation can no longer significantly decrease average coefficient of relationship. Because the majority of bull sires are Finnish bulls, average coefficient of relationship remains considerably high. It is possible that in the future average coefficient of relationship will continue to rise because the best AI-bulls are kept alive and they can produce semen continuously for many years.

Average coefficient of relationship of Finnish Holstein-Friesian bulls also varied considerably between age classes, the reasons are partly the same as for Ayrshire. The Holstein-Friesian bull sires and bulls are nearly all imported pure blood Holstein bulls and it is difficult to find completely new families that are not already represented in the Finnish Holstein-Friesian breed. However, the average coefficients of relationship increased annually relatively little during the study period, which is most likely due to the change of Finnish Friesian into Holstein-Friesian. In 1976, the share of Holstein genes of Finnish Friesian bulls was nil but in 1990 it was nearly 57\% (Lidauer and Mäntysaari 1996). Proportion of Holstein genes in British Holstein-Friesian bulls was $40 \%$ in 1992 but had risen to $57 \%$ in 1997 (Roughsedge et al. 1999). In the Dutch black and white dairy cattle population the proportion of Holstein genes was nearly $80 \%$ in 1992 (Te Braake et al. 1994).
The proportion of Holstein genes in Finnish Holstein-Friesian cows was 33\% in 1991(Lidauer and Mäntysaari 1996) and in 1999 the proportion was risen to $42.5 \%$ (J. Pösö, personal communication). Thus, the change from Friesian to HolsteinFriesian has not been as fast for cows as for bulls. In the current study, average coefficient of relationship of Finnish Holstein-Friesian cows increased very slowly and in the last few years average coefficient of relationship has slightly decreased. Increase in mean coefficient of relationship has been slower for cows than bulls in Ayrshire. The number of cows in age classes in both breeds is larger than the number of bulls, so it is obvious that cows are progeny of all available AIbulls and the effect of a few imported or elite bulls on average coefficient of relationship is diluted.

Mean coefficients of inbreeding in Ayrshire and Holstein-Friesian cows are relatively low and it seems that the increase in inbreeding has ceased. The mean coefficients of inbreeding of HolsteinFriesian bulls are very low compared to the average coefficient of relationship. So far importation has reduced the accumulation of inbreeding. This can be clearly seen if considering the proportion of completely non-inbred animals which in Holstein breed is much higher than in Ayrshire (Fig. 4). Although imported Holstein-Friesian bulls are from very small effective breeding populations (Weigel 2000), they have introduced completely new families to the Finnish Friesian population. In the future the proportion of Holstein genes in HolsteinFriesian bulls will increase, which is likely to increase the average coefficient of relationship and inbreeding. However, it is possible to restrict average coefficient of inbreeding at a low level by carefully selecting the mating pairs and the imported bulls.

\section{Conclusions}

The share of Holstein genes in Finnish HolsteinFriesian population has increased very slowly and this mainly explains the low coefficients of in- 
Vahlsten, T. et al. Coefficients of relationship among Finnish dairy cattle populations

breeding and relationships. Also it has to be kept in mind that pedigrees of some of the imported Holstein bulls are not complete as possible. The share of Holstein genes will increase faster in the future and it is likely to fasten the increase of inbreeding and relationship as well.

Although the average coefficient of relationship of Ayrshire bulls is very high in some age classes, the coefficient and increase of inbreeding have remained quite low in the Finnish Ayrshire population. At the end of the 1990s increase in the coefficient of inbreeding even ceased. However, increase is expected in the near future because average coefficient of relationship increased at the same time. If the average coefficient of relationship continues its rise, increase in inbreeding is likely to follow.

\section{References}

Casanova, L., Hagger, C., Kuenzi, N. \& Schneeberger, M. 1992. Inbreeding in Swiss Braunvieh and its influence on breeding values predicted from a repeatability animal model. Journal of Dairy Science 75: 1119-1126.

Falconer, D.S. \& Mackay, T.F.C. 1996. Introduction to quantitative genetics. 4th ed. Longman Group Ltd. 464 p.

FABA 2004. Finnish Animal Breeding Association. Updated February 2004. Cited 30 August 2004. URL: http:// www.faba.fi/english/index.html

Hermas, S.A., Young, C.W. \& Rust, J.W. 1987. Effects of mild inbreeding on productive and reproductive performance of Guernsey cattle. Journal of Dairy Science 70: 712-715.

Lidauer, M. \& Mäntysaari, E. 1996. Genetic constitution of the Finnish Black and White cattle population and the influence of Holsteinization on protein yield, days open and somatic cell count. Acta Agriculturae Scandinavica 46: 193-200.

Lindström, U. 1969. Genetic change in milk yield and fat percentage in artificially bred populations of Finnish dairy cattle. PhD Thesis, University of Helsinki. Acta Agralia Fennica 114. 128 p.

Lindström, U. 1978. Selection intensity for milk yield in 1970-1977 in the Finnish Ayrshire. Journal of the Scientific Agricultural Society of Finland 50: 445-454.

Lindström, U. \& Maijala, K. 1971. Development of the coefficients of inbreeding and relationship in the Finnish Ayrshire breed. Zeitschrift für Tierzüchtung and Züchtungsbiologie 87: 335-347.

Lonka, T. \& Myllylä, L. 1988. Friisiläinen karjarotu Suomessa (in Finnish). Finnish Animal Breeding Association, Vantaa. $26 \mathrm{p}$.

Mäntysaari, E.A. \& Strandén, I. 1991. Animal model evaluation for production and reproduction traits in Finnish dairy cattle. Proceedings of the 42nd Annual Meeting of the European Association of Animal Production, Berlin. Vol. 1. p. 96-97.

Meuwissen, T.H.E. \& Luo, Z. 1992. Computing inbreeding coefficients in large populations. Genetics Selection Evolution 24: 305-313.

Roughsedge, T., Brotherstone, S. \& Visscher, P.M. 1999. Quantifying genetic contributions to a dairy cattle population using pedigree analysis. Livestock Production Science 60: 359-369.

Simonen, S. 1950. Suomen Ayrshireyhdistyksen historia 1901-1951. In: History of the Finnish Ayrshire Society. Helsinki. 429 p.

Smith, L.A., Cassell, B.G. \& Pearson, R.E. 1998. The effects of inbreeding on the lifetime performance of dairy cattle. Journal of Dairy Science 81: 2729-2737.

Te Braake, M.F.H., Groen, A.F. \& Van Der Lugt, A.W. 1994. Trends in inbreeding in Dutch Black and White dairy cattle. Journal of Animal Breeding 111: 356-366.

Thompson, J.R., Everett, R.W. \& Hammerschmidt, N.L. 2000a. Effects of inbreeding on production and survival in Holsteins. Journal of Dairy Science 83: 1856-1864.

Thompson, J.R., Everett, R.W. \& Wolfe, C.W. 2000b. Effects of inbreeding on production and survival in Jerseys. Journal of Dairy Science 83: 2131-2138.

Weigel, K.A. 2000. Controlling inbreeding in modern breeding programs. Journal of Dairy Science 84, (E. Suppl.): E177-E184.

Wiggans, G.R., Van Raden, P.M. \& Zuurbier, J. 1995. Calculation and use of inbreeding coefficients for genetic evaluation of United States dairy cattle. Journal of Dairy Science 78: 1584-1590.

Woolliams, J.A. \& Mäntysaari, E.A. 1995. Genetic contributions of Finnish Ayrshire bulls over four generations. Animal Science 61: 177-187. 


\title{
SELOSTUS
}

\section{Sukulaisuus- ja sukusiitosaste Suomen ayrshire- ja holstein-friisiläispopulaatioissa}

\author{
Terhi Vahlsten, Esa A. Mäntysaari ja Ismo Strandén \\ MTT (Maa- ja elintarviketalouden tutkimuskeskus)
}

Keinosiemennysjalostuksessa sonnien valinta on erittäin intensiivistä, ja alkionsiirto on mahdollistanut myös lehmien intensiivisemmän valinnan. Populaation sukulaisuussuhteiden ja sukusiitosasteiden kehitystä pitää seurata säännöllisesti, koska populaation sukulaisuusasteen nousu johtaa väistämättä jonkin asteiseen sukusiitosasteen nousuun. Suomessa on tutkittu viimeksi ayrshiresonnien sukulaisuus- ja sukusiitosasteita 1980-luvulla, mutta suomalaista holstein-friisiläispopulaatiota ei ole aikaisemmin tutkittu.

Koelypsymallin sukulaisuustiedoilla laskettiin ayrshiresonnien ja -lehmien sekä holstein-friisiläissonnien ja -lehmien tämänhetkiset sukulaisuus- ja sukusiitosasteet sekä sukupolvien välinen aika. Koelypsymallin sukulaisuustiedosto sisältää kaikki arvostelussa mukana olevat eläimet 1980-luvun puolivälistä alkaen ja tätä vanhempien keinosiemennyssonnien sukutiedot. Sukulaisuus- ja sukusiitosaste laskettiin sonneille vuodesta 1976 vuoteen 1999 ja lehmille vuodesta 1986 vuoteen 1999 ikäluokittain eli laskettiin samana vuonna syntyneiden eläinten keskinäinen sukulaisuusaste ja keskimääräinen sukusiitosaste.

Sukupolvenväliset ajat laskettiin neljälle polulle. isä-poika, isä-tytär, emä-poika ja emä-tytär. Sukupolvenvälisissä ajoissa ei ole suuria eroja rotujen välillä. 1990-luvulla sukupolvenvälisissä ajoissa ei tapahtunut suuria muutoksia. Suuntaus on kuitenkin nuorempiin sonninisiin, joten sonnien isät valitaan heti, kun nuorsonneille saadaan arvostelut kaikista ominaisuuksista riittävän korkealla arvosteluvarmuudella.

Ayrshiresonnien sukulaisuusaste nousi 2,2 \%-yksikköä sukupolvea kohti, ja muutamien ikäluokkien keskimääräinen sukulaisuusaste oli 1990-luvun lopussa huolestuttavan korkealla. Ayrshirellä sonni-ikäluokkien välillä on suuria eroja keskimääräisessä sukulaisuusasteessa, joten sukulaisuusasteen nousu vuotta kohden on ollut hidasta vuodesta 1976 vuoteen 1999. Myös tuontisonnien käyttö sonninisinä on vaikuttanut ikäluokan keskimääräiseen sukulaisuusasteeseen, mutta tuontisonnien vaikutus on vähentynyt, koska suurin osa tuontisonneis- ta on ollut ruotsalaisia sonneja, joiden taustalta löytyy suomalaisia sonneja. Holstein-friisiläissonnien keskimääräisessä sukulaisuusasteessa on myös selviä eroja ikäluokkien välillä. Sukulaisuusaste on kuitenkin noussut hitaasti noin $1 \%$-yksikköä sukupolvea kohti ja tämä johtuu suurelta osin rodun muuttumisesta friisiläisestä holstein-friisiläiseksi. Molemmilla roduilla lehmien sukulaisuusaste on noussut hyvin hitaasti (ayrshirellä 0,4 $\%$-yksikköä sukupolvea kohti, holstein-friisiläisellä 0,3 $\%$-yksikköä sukupolvea kohti) ja 90-luvun lopussa hidas nousu pysähtyi.

1990-luvulla syntyneiden ayrshiresonnien- ja lehmien keskimääräinen sukusiitosaste oli 2,29 \% eli alhainen. Suuntaus on ollut kuitenkin kohti korkeampia sukusiitosasteita koko 90-luvun. Sukusiitosasteen nousu on kuitenkin hidasta, sillä ayrshiresonnien sukusiitosaste nousi keskimäärin 0,2 \%-yksikköä sukupolvea kohti ja lehmien sukusiitosasteen nousu oli keskimäärin 0,3\%yksikköä. Ayrshiresonnien sukusiitosasteen nousu saattaa tulevaisuudessa kiihtyä, mikäli keskimääräinen sukulaisuusaste ei laske. Holstein-friisiläisellä 90-luvulla syntyneiden sonnien ja lehmien keskimääräinen sukusiitosaste oli $0,9 \%$ ja suuntauksena on ollut sukusiitettyjen yksilöiden osuuden nousu, ei niinkään sukusiitosasteiden nousu. Holstein-friisiläissonnien sukusiitosaste nousi keskimäärin 0,2\%-yksikköä sukupolvea kohti ja lehmillä sukusiitosaste nousi keskimäärin $0,1 \%$-yksikköä sukupolvea kohti. Sukusiitosasteiden nousu on siis ollut hidasta.

Molempien rotujen sonneilla ja lehmillä sukusiitoksen nousu on ollut erittäin hidasta ja tämä selittyy osaksi sukusiitoksen rajoittamisella paritussuunnitelmia tehtäessä. Ayrshiresonnien sukulaisuusaste on noussut muutamissa ikäluokissa 1990-luvun lopulla jo huolestuttavan korkealle ja se saattaa tulevaisuudessa johtaa myös nopeampaan sukusiitosasteiden nousuun. Holstein-friisiläisten sonnien sukulaisuusaste ei ole noussut vielä kovinkaan korkealle ja myös lehmien sukulaisuusasteet ovat erittäin alhaisia ja tämä johtuu pääosin rodun muuttumisesta friisiläisestä holsteiniksi. 